\title{
MENINGOMYELOCELE: CASE REPORT WITH ITS EMBRYOLOGICAL BASIS
}

Abhijeet Yadav ${ }^{1}$

\section{HOW TO CITE THIS ARTICLE:}

Abhijeet Yadav. "Meningomyelocele: Case Report with its Embryological Basis". Journal of Evolution of Medical and Dental Sciences 2014; Vol. 3, Issue 26, June 30; Page: 7099-7101, DOI: 10.14260/jemds/2014/2865

ABSTRACT: Neural tube defects affect the tissues overlying the spinal cord: meninges, vertebral arches, muscles, and skin. Birth defects involving the embryonic neural arches are referred to as spina bifida. Spina bifida denotes non fusion of the halves of the embryonic neural arches, which is more common. Severe defects also involve the spinal cord, meninges and neurocranium. ${ }^{1}$ Meningomyelocele is a congenital disease in which a defect in the embryonal formation of the neural tube leading to malformation of the central nervous system, where parts of the meninges and spinal cord (myelon) emerge from the incompletely closed vertebral arches. ${ }^{2}$

KEYWORDS: Neural tube defect, meningocele, meningomyelocele.

INTRODUCTION: Spina bifida occurs when the bony vertebral arches fail to form properly, thereby creating a vertebral defect, usually in the lumbosacral region. Spina bifida occulta is evidenced by a tuft of hair in the lumbosacral region. It is the least severe variation and occurs in $10 \%$ of the population. Spina bifida with meningocele occurs when the meninges protrude through a vertebral defect and form a sac filled with CSF.

The spinal cord remains in its normal position. Spina bifida with meningomyelocele occurs when the meninges and spinal cord protrude through a vertebral defect and form a sac filled with CSF. Spina bifida with rachischisis occurs when the posterior neuropore of the neural tube fails to close during week 4 of development. This condition is the most severe type of spina bifida, causing paralysis from the level of the defect caudally. ${ }^{3}$

CASE REPORT: A neonate was brought to the OPD of pediatric surgery of Hamidia Hospital, Bhopal. The patient was full term normal vaginal delivery but with a defect in the thoraco-lumbar region which was present in midline. There was no history of folic acid tablet consumption by the mother. The local examination of the swelling revealed that it was circular to oval in shape with elevated margins and a central defect measuring approx. $9.5 \mathrm{~cm} \times 7.5 \mathrm{~cm}$. There was presence of yellow whitish tissue which resembled neural element. Neurological examination revealed poor reflexes. No other defect was present. The diagnosis of NEURAL TUBE DEFECT most likely meningomyelocele was made.

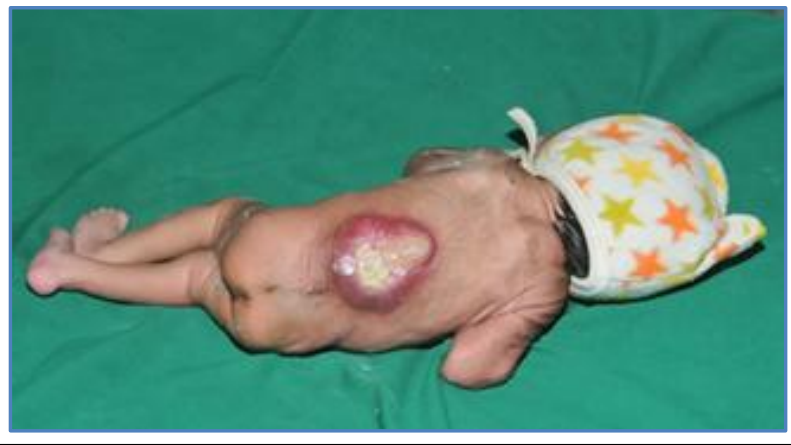

FIG.1: PATIENT WITH NEURAL TUBE DEFECT 


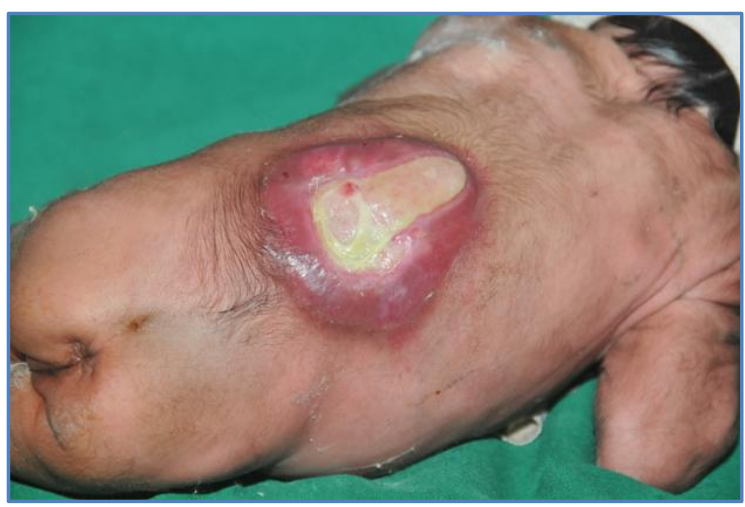

FIG. 2: CLOSER VIEW OF PATIENT WITH NEURAL TUBE DEFECT

DISCUSSION: Severe neural tube defects involving neural and non-neural structures occur in approximately $1 / 1000$ births, but the incidence varies among different populations and may be as high as $1 / 100$ births in northern china. ${ }^{4}$ Spina bifida with meningomyelocele is a more common and a more severe defect than spina bifida with meningocele. This neural tube defect may occur anywhere along the vertebral column, but lumbar and sacral region are more common. Some cases of meningomyelocele are associated with craniolacunia (defective development of calvaria). ${ }^{5}$

The child with meningomyelocele is born with a large externalized lumbosacral sac covered by delicate, weeping skin. There is severe dysfunction of the cauda equina roots or conus medullaris contained in the sac. As a rule the legs are motionless, urine dribbles, keeping the patient constantly wet. ${ }^{6}$ Meningomyelocele patients often have hydrocephalus and a Chiari II Malformation, an abnormal downward herniation of the cerebellum and brain stem through foramen magnum. ${ }^{7}$ The spinal cord is an open flat plate on the surface of the bulging meninges. There is no doubt that secondary postnatal injury may occur. An open meningomyelocele is liable to infections. ${ }^{8}$

Neural tube defects are common congenital disorders that can affect any portion of the neuraxis. During the $2^{\text {nd }}$ week of gestation, ectodermal cells proliferate near the midline of the embryo, forming the neural plate. At approximately day 17 of gestation, the neural plate invaginates and the lateral portions thicken, forming the neural folds. Meningomyeloceles represent the the most important clinical examples of disordered neurulation because most affected infants survive. The essential defect is a failure of closure of the caudal neuropore.

The resulting lesion by definition involves the spinal cord, a deficient axial skeleton, and an incomplete meningeal and dermal covering. Instead of forming into a tube, the neural folds persist as a flat plate of tissue referred as neural placode. Spinal defects include a lack of fusion of the vertebral arches, laterally displaced pedicles and a widened spinal canal. ${ }^{9}$

CONCLUSION:The thoracolumbar junction is the most common level affected (45\%), lumbar(20\%), lumbosacral (20\%) \& sacral (10\%). More rostral are involved in 5\% cases. ${ }^{9}$ Nutritional and environmental factors have been implicated. Both food fortification with folic acid and folic acid supplements taken before conception and continued for atleast 3 months during pregnancy reduce the incidence of neural tube defects. ${ }^{10}$

The aim of treatment of spinabifida is to provide patient with utmost level of mobility and independence which is possible through optimized therapeutic aids. This therefore requires a team of 


\section{CASE REPORT}

pediatric surgeon, neurosurgeon, pediatrician, physiotherapist, neurologist and other superspecialists. Counseling of parents is also very important.

\section{REFERENCES:}

1. Moore K. L, Persaud TVN., Torchia M. G. The Developing Human 9th ed. Elseviers, 2013; 398.

2. Harms J. www.harms-spinesurgery.com; 2007;1.

3. Dudek R.W. Embryology. $5^{\text {th }}$ ed. Wolters Kluwer, 2011;86-87.

4. Sadler T.W. Langman's medical embryology.11th ed. Wolter Kluwer, 2010; 302.

5. Moore KL, Persaud TVN., Torchia M.G. The Developing Human 9th ed. Elseviers, 2013; 402.

6. Adams \& Victor's principles of neurology. $8^{\text {th }}$ ed. McGraw hill; 860.

7. Schwartz's principles of surgery. $9^{\text {th }}$ ed. McGraw hill; 1553.

8. Forfar \& Arneil's. Textbook of Pediatrics. $7^{\text {th }}$ ed. Curchill Livingstone, Elsevier; 826.

9. Sabiston textbook of surgery. The biological basis of modern surgical practice vol.2.17th ed. Elseviers; 2171-2172.

10. Moore KL, Persaud TVN, Torchia M.G, The Developing Human 9th ed. elseviers, 2013;

\section{AUTHORS:}

1. Abhijeet Yadav

\section{PARTICULARS OF CONTRIBUTORS}

1. Assistant Professor, Department of Anatomy, Bundelkhand Medical College, Sagar.

\section{NAME ADDRESS EMAIL ID OF THE} CORRESPONDING AUTHOR:

Abhijeet Yadav,

Flat No. 8, Block 9,

Tili Road, Shivaji Ward, Bundelkhand Medical College Campus,M. P. Email: dr.abhijeetrocks@gmail.com

Date of Submission: 14/06/2014. Date of Peer Review: 16/06/2014. Date of Acceptance: 20/06/2014. Date of Publishing: 24/06/2014. 